\title{
FGF5 wt Allele
}

National Cancer Institute

\section{Source}

National Cancer Institute. FGF5 wt Allele. NCI Thesaurus. Code C51500.

Human FGF5 wild-type allele is located within $4 \mathrm{q} 21$ and is approximately $24 \mathrm{~kb}$ in length.

This allele, which encodes fibroblast growth factor 5 protein, is involved in cellular growth and proliferation. Aberrant allelic activity was capable of oncogenic transforming activity when transfected into mammalian cells. 